\title{
Revision of type specimens of Astaena (Coleoptera: Scarabaeidae: Melolonthinae: Sericini) described by L.W. Saylor
}

\author{
Thaynara L. PACHECO ${ }^{1, *}$, Marcela L. MONNÉ ${ }^{2}$, \\ Fernando Z. VAZ-DE-MELLO ${ }^{3} \&$ Dirk AHRENS $^{4}$ \\ ${ }^{1}$ Laboratório de Coleoptera, Departamento de Entomologia, Museu Nacional, \\ Universidade Federal do Rio de Janeiro, Rio de Janeiro, Brazil. \\ ${ }^{1,4}$ Centre of Taxonomy and Evolutionary Research, \\ Zoologisches Forschungsmuseum Alexander Koenig, Bonn, Germany. \\ ${ }^{2}$ Laboratório de Coleoptera, Departamento de Entomologia, Museu Nacional, \\ Universidade Federal do Rio de Janeiro, Rio de Janeiro, Brazil. \\ ${ }^{3}$ Laboratório de Scarabaeoidologia, Departamento de Biologia e Zoologia, \\ Instituto de Biociências, Universidade Federal de Mato Grosso, Cuiabá, Brazil. \\ *Corresponding author: thay.lpacheco@gmail.com \\ 2Email:mlmonne2@gmail.com \\ ${ }^{3}$ Email: vazdemello@gmail.com \\ ${ }^{4}$ Email: ahrens.dirk_col@gmx.de

\footnotetext{
${ }^{1}$ urn:1sid:zoobank.org:author:146CF81B-1394-456C-A768-BFFDE3E213D0

${ }^{2}$ urn:1sid:zoobank.org:author:86B186B4-4297-4380-A98D-FC813B5D53A6

${ }^{3}$ urn:lsid:zoobank.org:author:2FF2B7D6-1A6B-43C1-9966-A1A949FB2B05
} \\ ${ }^{4}$ urn:lsid:zoobank.org:author:DEDCE5CF-AA11-4BBF-A2C6-D7C815019714
}

\begin{abstract}
This is the first part of a revision of the type specimens of the South American Sericini. Herein, we examine type specimens of Astaena described by Lawrence Webster Saylor (1913-1999). We provide diagnostic redescriptions, images of habitus, aedeagus, and labels of the type specimens of all 18 species described by him in the genus Astaena. We raise Sayloria Frey, 1973, a former subgenus of Symmela Erichson, 1835 that includes three species, to genus level. Our study results in the following new combinations and synonymy: Sayloria bicoloripes (Saylor, 1946) comb. nov. (= A. postnodata Frey, 1973 syn. nov.), S. abcora (Saylor, 1946) comb. nov. (= A. apolinarmaria Saylor, 1946 syn. nov.) and $S$. pottsi (Saylor, 1946) comb. nov.
\end{abstract}

Keywords. Chafers, Sayloria, taxonomy, Neotropical region, South America.

Pacheco T.L., Monné M.L., Vaz-De-Mello F.Z. \& Ahrens D. 2021. Revision of type specimens of Astaena (Coleoptera: Scarabaeidae: Melolonthinae: Sericini) described by L.W. Saylor. European Journal of Taxonomy 750: 94-123. https://doi.org/10.5852/ejt.2021.750.1365

\section{Introduction}

Sericini Kirby, 1837 is a monophyletic tribe of chafer beetles with a nearly worldwide distribution, that is absent only in Australia and circumpolar regions (Ahrens 2006a; Eberle et al. 2017a). It comprises 
PACHECO T.L. et al., Type specimens of Astaena described by Saylor

about 4000 species allocated in 200 genera (Ahrens 2006a). While Sericini are still generally poorly known in terms of their taxonomy and systematics, some significant progress has been made over the past two decades with hundreds of new species of Sericini discovered in Asia and Africa (e.g., Ahrens 2004a; Fabrizi \& Ahrens 2014; Ahrens \& Fabrizi 2016; Eberle et al. 2017b; Fabrizi et al. 2019a, 2019b; Liu et al. 2019). However, South American species are still comparatively poorly known (Smith \& Evans 2005). For South America, around 250 nominal taxa have been described previously. The latest comprehensive treatment was a synopsis by Frey (1973). However, the recognition of most species is still very difficult since many species have been described based on female specimens and so far, comprehensive illustrations of species morphology are scarce.

The systematic status of South American Sericini received, however, several important recent updates: several genera have been excluded from Sericini (e.g., Athlia Erichson, 1835 and Dihymenonyx Gutiérrez, 1949 are now placed in Athliini Smith \& Evans, 2018 (Smith \& Evans 2018); Blepharotoma Blanchard, 1850 (Sericini according to Frey 1973) was transferred initially to Liparetrini Burmeister, 1855 (Evans \& Smith 2005; Katovich 2008) but has since been moved to Sericoidini Burmeister, 1855 (Smith 2008)) or their synonymy with non-Neotropical Sericini genera was recognized and are no longer considered elements of the Neotropical fauna (e.g., Rhynchosymmela Frey, 1974 was synonymized with Maladera Mulsant \& Rey, 1871 (subgenus Hemiserica Brenske, 1894; Ahrens 2004b)). Currently, four genera are recognized for the Neotropics, Symmela Erichson, 1835, Astaena Erichson, 1847, Raysymmela Saylor, 1947, and Miotemna Lacordaire, 1855 (Evans \& Smith 2005).

This work is part one of a series of studies with the common goal to re-examine and redescribe the type specimens of species of Sericini from South America, to designate lectotypes or neotypes where necessary, to revise their taxonomic status, and to produce high-quality images from the type specimens and their labels. In this way, we hope to facilitate correct identification of the species for future work, thus increase our ability to recognize as yet undescribed species, and make taxonomic information available for applied research including ecological, phylogenetic and biogeographical issues.

Most South American species of Sericini were described by German entomologists, such as Erichson (1835, 1847), Burmeister (1855), Kirsch (1865, 1885), Moser (1918, 1921a, 1921b, 1924, 1926), and Frey $(1973,1974,1975,1976)$, and their type specimens are housed in European collections (Evans 2003). However, numerous species were described by Lawrence W. Saylor (1913-1999; Ratcliffe 2016). During the visit of the first author (TLP) to the United States National Museum, Smithsonian Institute, Washington DC (USNM), it was possible to borrow and examine the Saylor type specimens of Sericini from the Californian Academy of Sciences, thus facilitating the first part of this taxonomic revision. Here we revise the type material of 18 species (of 19 total species in total) of South American Sericini described by L.W. Saylor, providing redescriptions and systematic assessments of the species. Raysymmela huanuca Saylor, 1947 (Saylor 1947a) was not included in this work. It will be treated in the framework of a separate revision of this genus.

\section{Material and methods}

Specimens studied for this work are all housed at the California Academy of Sciences, San Francisco, USA (CAS). All pictures were taken using a Canon EOS 5D Mark III (22.3 megapixels), lens Canon MP-E $65 \mathrm{~mm}$ with Passport II portable digital imaging system. Posteriorly they are stacked using the Zerene Stacker system ver. 1.04. Figure plates were edited with Adobe Photoshop CS3. Maps were generated with QGIS ver. 3.4. Diagnostic descriptions were generated from a nexus file, which was created in Mesquite ver. 3.61 (Maddison \& Maddison 2018) and subsequently fine-edited by hand. The label data of type specimens are given verbatim in quotation marks; different labels are separated by a forward slash (/). 


\section{Repositories}

CAS $=$ California Academy of Sciences, San Francisco, California, USA

$\mathrm{CMNC}=$ Canadian Museum of Nature, Ottawa, Canada

MNHN = Muséum national d'histoire naturelle, Paris, France

NHMB = Naturhistorisches Museum, Basel, Switzerland

SMTD $=$ Staatliches Museum für Tierkunde, Dresden, Germany

ZFMK = Zoologisches Forschungsinstitut und Museum A. Koenig, Bonn, Germany

ZMHB = Zoologisches Museum der Humboldt-Universität, Berlin, Germany

\section{Results}

Class Insecta Linnaeus, 1758

Subclass Pterygota Lang, 1888

Order Coleoptera Linnaeus, 1758

Superfamily Scarabaeoidea Latreille, 1802

Family Scarabaeidae Latreille, 1802

Subfamily Melolonthinae Leach, 1819

Tribe Sericini Kirby, 1837

Genus Astaena Erichson, 1847

Astaena Erichson, 1847: 101.

Temnostoma Blanchard, 1850: 84.

Astaena - Frey 1973: 325 (identification key). — Evans 2003: 18 (checklist). — Evans \& Smith 2005: 4 (checklist); 2007: 4 (checklist); 2009: 4 (checklist).

Temnostoma - Lacordaire 1856: 208 (synonymy).

\section{Type species}

Astaena tridentata Erichson, 1847 (by monotypy).

\section{Diagnosis}

Brown or reddish-brown coloration, mostly unicolored. Antennae with eight or nine antennomeres; antennal club with three antennomeres. Abdomen with a lateral carina.

\section{Astaena abaca Saylor, 1946}

Figs $1 \mathrm{~A}-\mathrm{D}, 7 \mathrm{~A}$

Astaena abaca Saylor, 1946: 223.

Astaena abaca - Frey 1973: 354 (identification key). — Evans 2003: 19 (checklist). — Evans \& Smith 2005: 4 (checklist); 2007: 4 (checklist); 2009: 4 (checklist).

\section{Type material examined}

\section{Holotype}

COLOMBIA • $q$; "Paine viii Colum. / Apolinar-Maria / L.W. Saylor Collection / California Academy of Sciences Type n 7904 / Holotype Astaena abaca L.W. Saylor”; CAS. 


\section{Holotype redescription}

Measurements. Length: $12 \mathrm{~mm}$. Width: $5.8 \mathrm{~mm}$.

HEAD. Reddish-brown, surface with simple setae. Labroclypeus convex, shape of anterior margin convex, posteriorly with sparse punctation. Ratio ocular canthus (measured just the process on the eye)/eye (measured along longitudinal axis): 1/4. Antennae with eight antennomeres; antennal club with three antennomeres; ratio antennal club/remaining antennomeres: $1 / 1.5$; ratio third vs fourth antennomere: $1 / 2$; fourth antennomere, lateral projection absent; ratio fifth vs fourth antennomere: $1 / 5$.

Pronotum AND elytra. Surface of pronotum and elytra with setae. Pronotum unicolored, reddishbrown, widest at middle, anterior marginal line present, lateral margin strongly convex and smooth (not serrated), antero-lateral angle dorso-ventrally flattened, postero-lateral angle dorso-ventrally not flattened, punctation on disc sparse, median longitudinal excavation absent. Scutellum, punctures absent medially. Elytra unicolored, reddish-brown, surface tegument opaque, microsculpture absent, punctation on intervals present, strial and interval punctation equal in size.

AвDOMEN. Lateral carina present. Second visible ventrite with row of setae in medial region. Apical visible ventrite without suture to apical tergite.

Legs. Metacoxa without longer lateral bristles, setae on basal surface present, a laterally extended longitudinal shelf present. Metatibia, widest at apex, dorsal margin carinate, ventral margin smooth (not serrated), distal spines groups disposed at two thirds of metatibial length. First metatarsomere, ratio to dorsal metatibial spur: 1/2. Dorsal surface of tarsi glabrous. Metatarsi, length of first protarsomere subequal to second and third combined, ventral margin serrated and setose. Protibia with three teeth. Protarsi, second protarsomere narrow, claws symmetrical, inner protarsal claw bifid, apex of basal tooth of inner protarsal claw acute.

\section{Male}

Unknown.

Astaena biciliata Saylor, 1946

Figs 1E-I, 7A

Astaena biciliata Saylor, 1946: 219.

Astaena biciliata - Frey 1973: 335, 347 (identification key). — Evans 2003: 19 (checklist). — Evans \& Smith 2005: 5 (checklist); 2007: 5 (checklist); 2009: 5 (checklist).

\section{Type material examined}

\section{Holotype}

PERU • O'; "ix-20-35 M. Sani Beni Lima Peru, 35 / L.W. Saylor Collection / California Academy of Sciences Type no 7907 / Holotype Astaena biciliata L.W. Saylor"; CAS.

\section{Paratype}

PERU • 1 क; "ix-20-35 M. Sani Beni Lima Peru, 35 / L.W. Saylor Collection / Collection of the California Academy of Sciences, San Francisco, California / Allotype Astaena biciliata L.W. Saylor / CASENT 8438128"; CAS. 


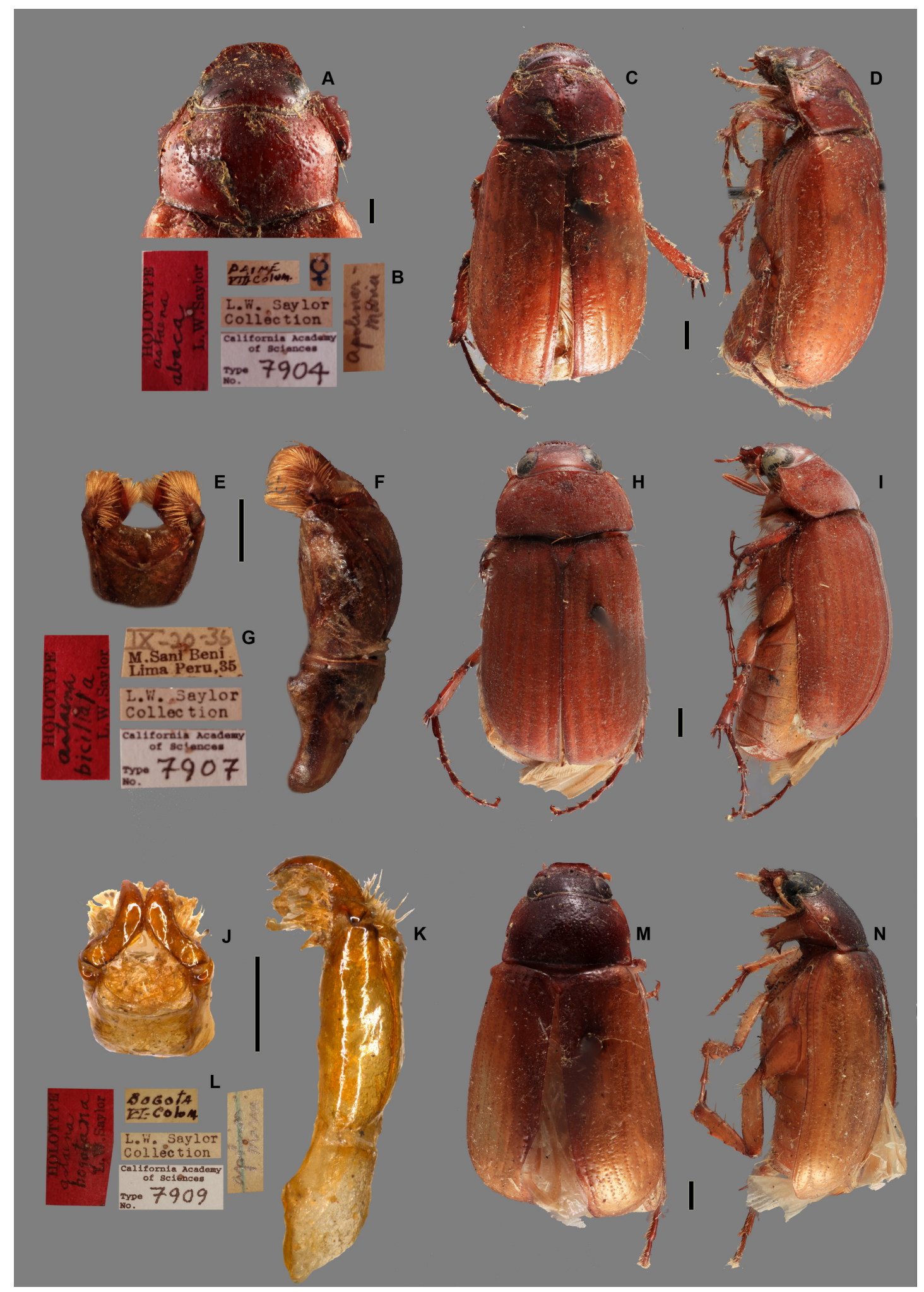

Fig. 1. A-D. Astaena abaca Saylor, 1946, holotype, $q$ (Type No. 7904; CAS). - E-I. A. biciliata Saylor, 1946, holotype, ठ̊ (Type No. 7907; CAS). - J-K. A. bogotana Saylor, 1946, paratype, §̂ (CAS). - L-N. A. bogotana, holotype, §̂ (Type No. 7909; CAS). A. Head and pronotum, dorsal view. B, G, L. Labels. C, H, M. Habitus, dorsal view. D, I, N. Habitus, lateral view. E, J. Parameres, dorsal view. F, K. Aedeagus, lateral view. Scale bars: A, E-F, J-K $=0.5 \mathrm{~mm} ; \mathrm{C}-\mathrm{D}, \mathrm{H}-\mathrm{I}, \mathrm{M}-\mathrm{N}=1 \mathrm{~mm}$. 


\section{Holotype redescription}

Measurements. Length: $11 \mathrm{~mm}$. Width: $5.6 \mathrm{~mm}$.

HEAD. Reddish-brown, surface with upright setae. Labroclypeus, shape of anterior margin convex, posteriorly with sparse punctation. Ocular canthus with terminal setae, ratio to eye: $1 / 4$. Eyes, ratio diameter/interocular width: 0.55. Antennae with eight antennomeres; antennal club with three antennomeres; ratio antennal club/remaining antennomeres: $1 / 1$; ratio third vs fourth antennomere: $1 / 4$; fourth antennomere, lateral projection absent; ratio fifth vs fourth antennomere: 1/5.

Pronotum AND Elytra. Surface of pronotum and elytra without setae. Pronotum unicolored, reddishbrown, widest at base, anterior marginal line present, posterior marginal line absent, lateral margin weakly convex and smooth (not serrated), antero-lateral angle dorso-ventrally not flattened, posterolateral angle dorso-ventrally not flattened, punctation on disc sparse, setae of lateral margin sparse, median longitudinal excavation absent. Scutellum, punctures absent medially. Elytra unicolored, reddishbrown, surface opaque, microsculpture absent, punctation on intervals present and dense, diameter of strial and interval punctation equal, posterior edge straight.

AвDOMEN. Lateral carina present. Second visible ventrite with row of setae in medial region. Apical visible ventrite without suture to apical tergite.

LEGS. Ratio of length of metepisternum/metacoxa: 1/0.77. Metacoxa without longer lateral bristles, a laterally extended longitudinal shelf present. Metatibia, widest at apex, ratio of width/length: 1/2.69, dorsal margin not carinated, ventral margin not serrated, distal spines groups disposed at two thirds of metatibial length. First metatarsomere, ratio to dorsal metatibial spur 1/2. Dorsal surface of tarsi glabrous and without punctures. Metatarsi, length of first protarsomere smaller than second and third combined, ventral margin not serrated and setose. Protibia with three teeth. Protarsi, length of first protarsomere subequal to second and third combined, second protarsomere narrow, claws symmetrical, inner protarsal claw bifid, apex of basal tooth of inner protarsal claw acute.

Aedeagus. Fig. 1E-F.

Astaena bogotana Saylor, 1946

Figs $1 \mathrm{~J}-\mathrm{N}, 7 \mathrm{~A}$

Astaena bogotana Saylor, 1946: 228.

Astaena bogotana - Frey 1973: 341 (identification key). — Evans 2003: 20 (checklist). — Evans \& Smith 2005: 5 (checklist); 2007: 5 (checklist); 2009: 5 (checklist).

\section{Type material examined}

Holotype

COLOMBIA • ○’; "Bogota vi- Colom. / Apolinar-Maria / L.W. Saylor Collection / California Academy of Sciences Type no 7909 / Holotype Astaena bogotana L.W. Saylor"; CAS.

Paratype

COLOMBIA - 1 ふ̄; "Bogota vi- Colom. / L.W. Saylor Collection / Paratype Astaena bogotana L.W. Saylor / CASENT 8438130"; CAS.

\section{Holotype redescription}

MEASUREMENTS. Length: $12 \mathrm{~mm}$. Width: $5.8 \mathrm{~mm}$. 
HEAD. Reddish-brown, surface with setae. Labroclypeus, shape of anterior margin convex. Ratio ocular canthus/eye: 1/4. Antennae with eight antennomeres; antennal club with three antennomeres; ratio antennal club/remaining antennomeres: $1 / 1$; ratio third vs fourth antennomere: $1 / 4$; fourth antennomere, lateral projection absent; ratio fifth vs fourth antennomere: $1 / 5$.

Pronotum AND ELYTRA. Surface of pronotum and elytra without setae. Pronotum unicolored, reddishbrown, widest at base, anterior marginal line present, posterior marginal line absent, lateral margin weakly convex and not serrated, antero-lateral angle dorso-ventrally flattened, postero-lateral angle dorso-ventrally flattened, median longitudinal excavation absent. Scutellum, punctures absent medially. Elytra bicolored, surface opaque, microsculpture absent, punctation on intervals present and sparse, diameter of strial and interval punctation equal.

AвDOMEn. Lateral carina present. Apical visible ventrite without suture to apical tergite.

LEGS. Metacoxa without longer lateral bristles, a laterally extended longitudinal shelf present. Metatibia, widest at apex, distal spines groups disposed at two thirds of metatibial length. First metatarsomere, ratio to dorsal metatibial spur 1/3. Metatarsi, length of first protarsomere smaller than second and third combined, ventral margin serrated and setose. Protibia with three teeth. Protarsi, length of first protarsomere subequal to second and third combined, second protarsomere narrow, claws symmetrical, inner protarsal claw bifid, apex of basal tooth of inner protarsal claw acute.

Aedeagus. Fig. 1 J-K.

Astaena excisipes Saylor, 1947

Figs 2A-D, 7A

Astaena excisipes Saylor, 1947b: 433.

Astaena excisipes - Frey 1973: 347 (identification key). — Evans 2003: 22 (checklist). — Evans \& Smith 2005: 7 (checklist); 2007: 7 (checklist); 2009: 7 (checklist).

\section{Type material examined}

Holotype

ECUADOR • P; "Ecuador Baron / Coll. Kraatz/ L.W. Saylor Collection / California Academy of Sciences Type $\mathrm{n}^{\circ} 7910$ / Astaena producta Bates? / Moser det. / Holotype Astaena excisipes L.W. Saylor"; CAS.

\section{Holotype redescription}

MEasurements. Length: $9.5 \mathrm{~mm}$. Width: $4.7 \mathrm{~mm}$.

HEAD. Reddish-brown. Labroclypeus, shape of anterior margin weakly sinuated medially. Ocular canthus with terminal setae, ratio to eye: $1 / 4$. Ratio third vs fourth antennomere: $1 / 4$. Fourth antennomere, lateral projection absent. Ratio fifth vs fourth antennomere: $1 / 5$.

PRonotum AND ELYTRA. Surface of pronotum and elytra without setae. Pronotum unicolored, reddishbrown, widest at middle, anterior marginal line present, posterior marginal line absent, lateral margin straight and not serrated, two angles on postero-lateral margin present, antero-lateral angle dorsoventrally not flattened, postero-lateral angle dorso-ventrally not flattened, punctation on disc dense, median longitudinal excavation absent. Scutellum, punctures absent medially. Elytra unicolored, reddishbrown, surface opaque, microsculpture absent, punctation on intervals present and dense, diameter of strial and interval punctation equal. 
AвDomen. Lateral carina present. Second visible ventrite without row of setae in medial region. Apical visible ventrite without suture to apical tergite.

LeGs. Metacoxa without longer lateral bristles, a laterally extended longitudinal shelf present. Metatibia, widest at apex, dorsal margin not carinated, ventral margin serrated, distal spines groups disposed at two thirds of metatibial length. First metatarsomere, ratio to dorsal metatibial spur: 1/2. Dorsal surface of tarsi glabrous, without punctures. Metatarsi, length of first protarsomere smaller than second and third combined, ventral margin serrated and setose. Protibia with three teeth. Protarsi, length of first protarsomere subequal to second and third combined, second protarsomere narrow, claws symmetrical, inner protarsal claw bifid.

\section{Male}

Unknown.

\section{Remarks}

The holotype specimen is a female; Saylor (1946) incorrectly stated that the holotype as a male.

Astaena explaniceps Saylor, 1947

Figs 2E-I, 7A

Astaena explaniceps Saylor, 1947b: 436.

Astaena explaniceps - Frey 1973: 341 (identification key). — Evans 2003: 22 (checklist). — Evans \& Smith 2005: 7 (checklist); 2007: 7 (checklist); 2009: 7 (checklist).

\section{Type material examined}

\section{Holotype}

ARGENTINA • đ̃; "Salta Prov. Arg. S.A. / L.W. Saylor Collection / California Academy of Sciences Type no 7911 / Holotype Astaena explaniceps L.W. Saylor"; CAS.

\section{Holotype redescription}

MEASUREMENTs. Length: $9.2 \mathrm{~mm}$. Width: $3.8 \mathrm{~mm}$.

HEAD. Reddish-brown, surface with upright setae. Labroclypeus, shape of anterior margin convex, posteriorly with dense punctation. Ocular canthus with terminal setae, ratio to eye: $1 / 2$. Ratio third vs fourth antennomere: $1 / 3$. Fourth antennomere, lateral projection absent. Ratio fifth vs fourth antennomere: $1 / 5$.

PRONOTUM AND ELYTRA. Surface of pronotum and elytra with setae. Pronotum unicolored, reddish-brown, widest at middle, anterior marginal line present, posterior marginal line absent, lateral margin strongly convex and smooth (not serrate), antero-lateral angle dorso-ventrally flattened, postero-lateral angle dorso-ventrally flattened, punctation on disc dense, setae of lateral margin sparse, median longitudinal excavation absent. Scutellum, punctures absent medially. Elytra unicolored, reddish-brown, surface opaque, microsculpture absent, punctation on intervals present and sparse, diameter of strial and interval punctation equal.

ABDomEn. Lateral carina present. Second visible ventrite without row of setae in medial region. Apical visible ventrite without suture to apical tergite. 


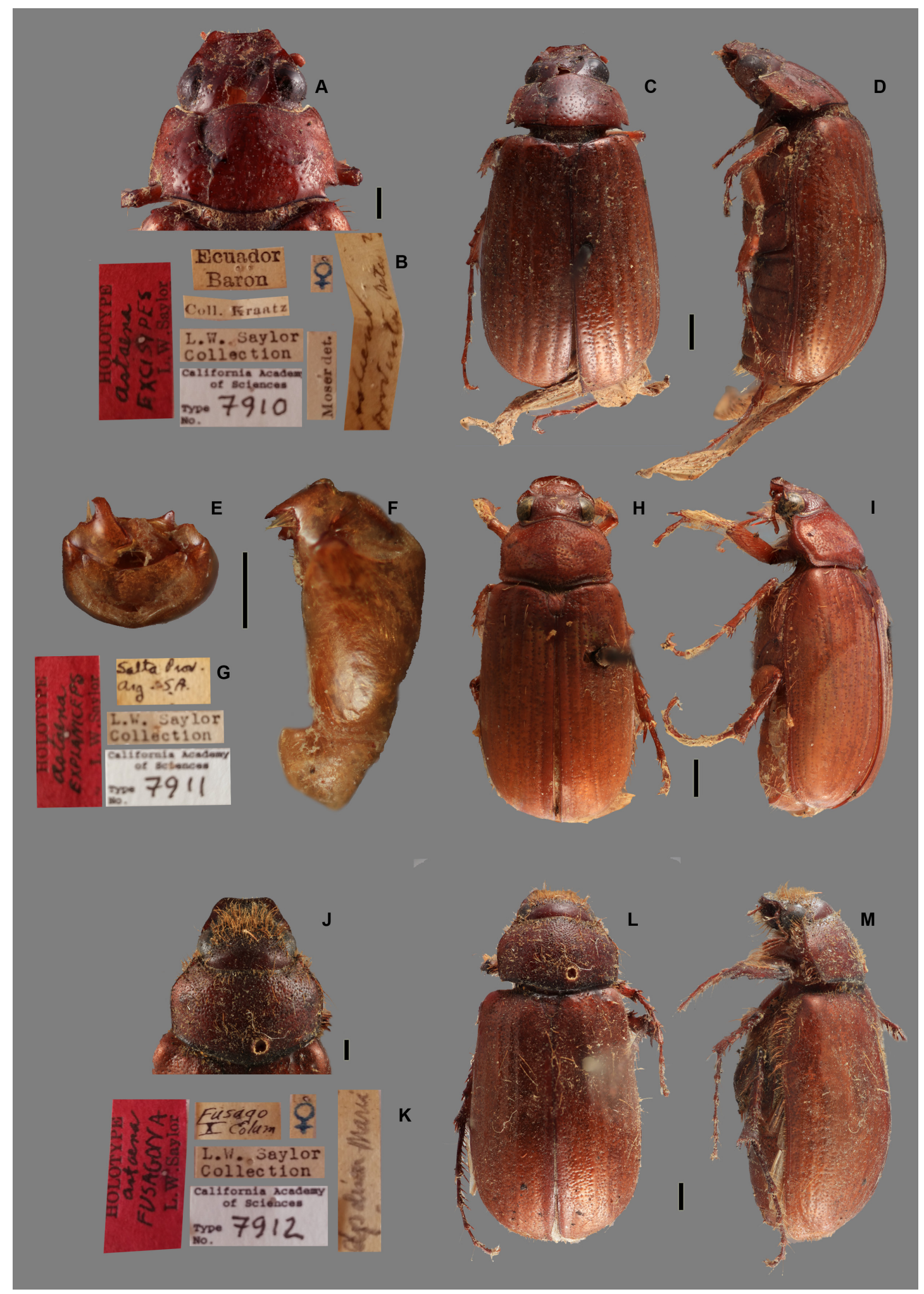

Fig. 2. A-D. Astaena excisipes Saylor, 1947, holotype, $q$ (Type No. 7910; CAS). - E-I. A. explaniceps Saylor, 1947, holotype, ô (Type No. 7911; CAS). - J-M. A. fusagona Saylor, 1946, holotype, + (Type No. 7912; CAS). A, J. Head and pronotum, dorsal view. B, G, K. labels. C, H, L. Habitus, dorsal view. D, I, M. Habitus, lateral view. E. Parameres, dorsal view. F. Aedeagus, lateral view. Scale bars: A, E-F, $\mathrm{J}=0.5 \mathrm{~mm} ; \mathrm{C}-\mathrm{D}, \mathrm{H}-\mathrm{I}, \mathrm{L}-\mathrm{M}=1 \mathrm{~mm}$. 
PACHECO T.L. et al., Type specimens of Astaena described by Saylor

LEGS. Metacoxa without longer lateral bristles, a laterally extended longitudinal shelf absent. Metatibia, widest at apex, dorsal margin carinated, distal spines groups disposed at two thirds of metatibial length. First metatarsomere, ratio to dorsal metatibial spur: 1/3. Dorsal surface of tarsi glabrous, with punctures. Metatarsi, length of first protarsomere subequal to second and third combined, ventral margin serrated. Protibia with three teeth. Protarsi, length of first protarsomere subequal to second and third combined, second protarsomere narrow, claws symmetrical, inner protarsal claw bifid, apex of basal tooth of inner protarsal claw acute.

Aedeagus. Fig. 2E-F.

Astaena fusagona Saylor, 1946

Figs 2J-M, 7B

Astaena fusagona Saylor, 1946: 221.

Astaena fusagona - Frey 1973: 329 (identification key). - Evans 2003: 23 (checklist). — Evans \& Smith 2005: 8 (checklist); 2007: 8 (checklist); 2009: 8 (checklist).

\section{Type material examined}

\section{Holotype}

COLOMBIA • ; " "Fusago x Colom / Apolinar-Maria / L.W. Saylor Collection / California Academy of Sciences Type n 7912 / Holotype Astaena fusagona L.W. Saylor"; CAS.

\section{Holotype redescription}

MeAsurements. Length: $13 \mathrm{~mm}$. Width: $6 \mathrm{~mm}$.

HEAD. Blackish-brown, surface with upright setae. Labroclypeus, shape of anterior margin weakly sinuated medially, posteriorly with dense punctation. Ocular canthus with terminal setae, ratio to eye: $1 / 3$. Antennae with eight antennomeres; antennal club with three antennomeres; ratio antennal club/remaining antennomeres: $1 / 1$; ratio third vs fourth antennomere: $1 / 4$; fourth antennomere, lateral projection absent; ratio fifth vs fourth antennomere: $1 / 5$.

Pronotum AND ElYTra. Surface of pronotum and elytra with upright setae. Pronotum unicolored, blackish-brown, widest at middle, anterior marginal line present, posterior marginal line absent, lateral margin strongly convex and smooth (not serrate), antero-lateral angle dorso-ventrally flattened, posterolateral angle dorso-ventrally not flattened, punctation on disc dense, setae of lateral margin dense, median longitudinal excavation absent. Scutellum, punctures medially present. Elytra unicolored, reddishbrown, surface opaque, microsculpture absent, punctation on intervals present and dense, diameter of strial and interval punctation equal.

AвDomen. Lateral carina present. Second visible ventrite with row of setae in medial region. Apical visible ventrite without suture to apical tergite.

LEGS. Metacoxa without longer lateral bristles, a laterally extended longitudinal shelf present. Metatibia, widest at apex, dorsal margin carinated, with group of spines positioned at two thirds of metatibial length. First metatarsomere, ratio to dorsal metatibial spur: 1/3. Dorsal surface of tarsi glabrous. Metatarsi, length of first protarsomere smaller than second and third combined, ventral margin serrated and setose. Protibia with three teeth. Protarsi, length of first protarsomere subequal to second and third combined, second protarsomere narrow, claws symmetrical, inner protarsal claw bifid, apex of basal tooth of inner protarsal claw acute. 
Male

Unknown.

Astaena incachaca Saylor, 1946

Figs 3A-E, 7A

Astaena incachaca Saylor, 1946: 215.

Astaena incachaca - Frey 1973: 329 (identification key). — Evans 2003: 23 (checklist). — Evans \& Smith 2005a: 9 (checklist); 2007: 9 (checklist); 2009: 9 (checklist).

\section{Type material examined}

Holotype

BOLIVIA - Ĵ; "Incachaca, Bolivia, Alt. 2500m, J. Steinbach, Acc. 6873 / L.W. Saylor Collection /

California Academy of Sciences Type no 7913 / Holotype Astaena incachaca L.W. Saylor"; CAS.

\section{Paratype}

BOLIVIA • 1 q, Incachaca, Bolivia, Alt. 2500m, J. Steinbach, Acc. 6873 / L.W. Saylor Collection

/ Collection of the California Academy of Sciences, San Francisco, California / Allotype Astaena incachaca L.W. Saylor / CASENT 8438145"; CAS.

\section{Holotype redescription}

MEASUREMENTs. Length: $11 \mathrm{~mm}$. Width: $5.6 \mathrm{~mm}$.

HEAD. Reddish-brown, surface with upright setae. Labroclypeus, shape of anterior margin straight, posteriorly with dense punctation. Ocular canthus with terminal setae, ratio to eye: $1 / 3$. Eyes, ratio diameter/interocular width: 0.56. Antennae with eight antennomeres; antennal club with three antennomeres; ratio antennal club/remaining antennomeres: $1 / 1$; ratio third vs fourth antennomere: $1 / 3$; fourth antennomere, lateral projection absent; ratio fifth vs fourth antennomere: 1/5.

Pronotum and elytra. Surface of pronotum and elytra with setae. Pronotum unicolored, reddishbrown, widest at middle, posterior marginal line absent, lateral margin strongly convex and smooth (not serrate), antero-lateral angle dorso-ventrally flattened, postero-lateral angle dorso-ventrally not flattened, punctation on disc sparse, setae of lateral margin dense, median longitudinal excavation absent. Scutellum, punctures absent medially. Elytra unicolored, reddish-brown, surface opaque, microsculpture absent, punctation on intervals present and sparse, diameter of strial and interval punctation equal.

Aвdomen. Lateral carina absent. Second visible ventrite without row of setae in medial region. Apical visible ventrite without suture to apical tergite.

LEGS. Ratio of length of metepisternum/metacoxa: 1/0.95. Metacoxa without longer lateral bristles, a laterally extended longitudinal shelf absent. Metatibia, widest at apex, ratio of width/length: 1/4.27, dorsal margin not carinated, ventral margin serrated, distal spines groups disposed at two thirds of metatibial length. First metatarsomere, ratio to dorsal metatibial spur: 1/2. Dorsal surface of tarsi glabrous, with punctures. Metatarsi, length of first protarsomere subequal to second and third combined, ventral margin serrated and setose. Protibia with three teeth. Protarsi, length of first protarsomere subequal to second and third combined, second protarsomere narrow, claws symmetrical, inner protarsal claw bifid, apex of basal tooth of inner protarsal claw acute.

Aedeagus. Fig. 3A-B. 
Astaena maqueta Saylor, 1947b: 434.

Astaena maqueta - Frey 1973: 326 (identification key). — Evans 2003: 24 (checklist). — Evans \& Smith 2005: 10 (checklist); 2007: 10 (checklist); 2009: 10 (checklist).

\section{Type material examined}

\section{Holotype}

ARGENTINA • O'; "Macueta Salta Prov. Arg. S.A. x-xi-32 / L.W. Saylor Collection / California Academy of Sciences Type $\mathrm{n}^{\circ} 7914$ / Holotype Astaena maqueta L.W. Saylor”; CAS.

\section{Paratypes}

ARGENTINA • 1 क; "Macueta Salta Prov. Arg. SA. x-xi-33 / L.W. Saylor Collection / Collection of the California Academy of Sciences, San Francisco, California / Allotype Astaena maqueta L.W. Saylor"; CAS • 1 ô; "Macueta Salta Prov. Arg. SA. x-xi-33 / L.W. Saylor Collection / Paratype Astaena maqueta L.W. Saylor / CASENT 8438172”; CAS.

\section{Holotype redescription}

MEASUREMENTs. Length: $12 \mathrm{~mm}$. Width: $5.8 \mathrm{~mm}$.

HEAD. Reddish-brown, surface with upright setae. Labroclypeus, shape of anterior margin convex, posteriorly with dense punctation. Ocular canthus with terminal setae, ratio to eye: $1 / 2$. Antennae with eight antennomeres; antennal club with three antennomeres; ratio antennal club/remaining antennomeres: $1 / 1$; ratio third vs fourth antennomere: $1 / 3$; fourth antennomere, lateral projection absent; ratio fifth vs fourth antennomere: $1 / 5$.

Pronotum AND elytra. Pronotum and elytra surface with upright setae. Pronotum unicolored, reddishbrown, widest at middle, anterior marginal line present, posterior marginal line absent, lateral margin weakly convex and not serrated, antero-lateral angle dorso-ventrally flattened, postero-lateral angle dorso-ventrally not flattened, punctation on disc dense, setae of lateral margin dense, median longitudinal excavation absent. Scutellum, punctures absent medially. Elytra unicolored, reddish-brown, surface opaque, microsculpture absent, punctation on intervals present and dense, diameter of strial and interval punctation equal.

AвDOMEn. Lateral carina present. Second visible ventrite with row of setae in medial region. Apical visible ventrite without suture to apical tergite.

LEGS. Metacoxa without longer lateral bristles, a laterally extended longitudinal shelf present. Metatibia, widest at apex, dorsal margin not carinated, distal spines groups disposed at two thirds of metatibial length. First metatarsomere, ratio to dorsal metatibial spur: 1/2. Dorsal surface of tarsi glabrous, with punctures. Metatarsi, length of first protarsomere subequal to second and third combined, ventral margin serrated and glabrous. Protibia with three teeth. Protarsi, length of first protarsomere subequal to second and third combined, second protarsomere narrow, claws asymmetrical, inner protarsal claw bifid, apex of basal tooth of inner protarsal claw truncate.

Aedeagus. Fig. 3F-G. 


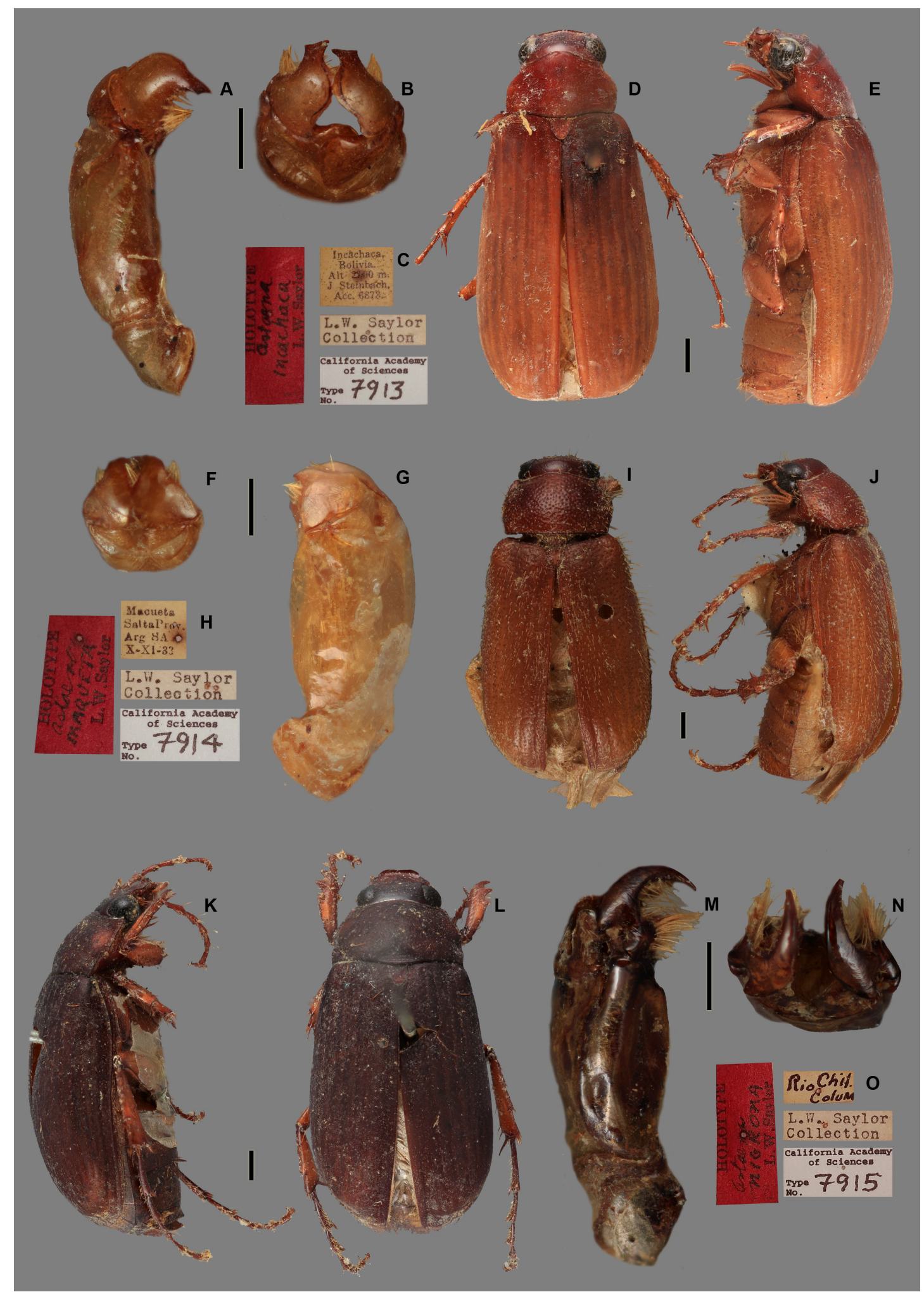

Fig. 3. A-E. Astaena incachaca Saylor, 1946, holotype, ठ̊ (Type No. 7913; CAS). - F-J. A. maqueta Saylor, 1947, holotype, ô (Type No. 7914; CAS). - K-O. A. nigrona Saylor, 1947, holotype, ô (Type No. 7915; CAS). A, G, M. Aedeagus, lateral view. B, F, N. Parameres, dorsal view. C, H, O. labels. D, I, L. Habitus, dorsal view. E, J, K. Habitus, lateral view. Scale bars: A-B, F-G, M-N = $0.5 \mathrm{~mm}$; D-E, $\mathrm{I}-\mathrm{L}=1 \mathrm{~mm}$. 
Astaena nigrona Saylor, 1947b: 435.

Astaena nigrona - Frey 1973: 331 (identification key).

non Astaena nigroana (incorrect subsequent spelling) - Evans 2003: 25 (checklist). — Evans \& Smith 2005: 10 (checklist); 2007: 10 (checklist); 2009: 10 (checklist).

\section{Type material examined}

\section{Holotype}

COLOMBIA • đa; "Rio Chil. Colum / L.W. Saylor Collection / California Academy of Sciences Type no 7915 / Holotype Astaena nigrona L.W. Saylor"; CAS.

\section{Paratype}

COLOMBIA • 1 q; "Bogota VI- Colum / L.W. Saylor Collection / Collection of the California Academy of Sciences, San Francisco, California / Allotype Astaena nigrona L.W. Saylor”; CAS.

\section{Holotype redescription}

Measurements. Length: $12 \mathrm{~mm}$. Width: $5.8 \mathrm{~mm}$.

HEAD. Reddish-brown. Labroclypeus, shape of anterior margin weakly sinuated medially. Ocular canthus without terminal setae, ratio to eye: $1 / 4$. Antennae with eight antennomeres; antennal club with three antennomeres; ratio antennal club/remaining antennomeres: $1 / 1.5$; ratio third vs fourth antennomere: $1 / 3$; fourth antennomere, lateral projection absent; ratio fifth vs fourth antennomere: $1 / 5$.

Pronotum AND ELYTRA. Surface of pronotum and elytra with setae. Pronotum bicolored, reddish-brown with two red spots on laterals, widest at middle, anterior marginal line present, posterior marginal line absent, lateral margin strongly convex and smooth (not serrate), antero-lateral angle dorso-ventrally flattened, postero-lateral angle dorso-ventrally flattened, punctation on disc dense, setae of lateral margin sparse, median longitudinal excavation absent. Scutellum, punctures absent medially. Elytra unicolored, blackish-brown, surface opaque, microsculpture absent, punctation on intervals present, diameter of strial and interval punctation equal.

ABDomen. Lateral carina present. Second visible ventrite with row of setae in medial region. Apical visible ventrite without suture to apical tergite.

LEGS. Metacoxa without longer lateral bristles, a laterally extended longitudinal shelf present. Metatibia, widest at apex, distal spines groups disposed at two thirds of metatibial length. First metatarsomere, ratio to dorsal metatibial spur: 1/3. Dorsal surface of tarsi glabrous, without punctures. Metatarsi, length of first protarsomere subequal to second and third combined, ventral margin serrated. Protibia with three teeth. Protarsi, length of first protarsomere subequal to second and third combined, second protarsomere narrow, claws asymmetrical, inner protarsal claw bifid, apex of basal tooth of inner protarsal claw truncate.

Aedeagus. Fig. 3M-N. 


\section{Astaena pygidia Saylor, 1946}

Figs 4A-E, 7B

Astaena pygidia Saylor, 1946: 230.

Astaena pygidia - Frey 1973: 339 (identification key). — Evans 2003: 28 (checklist). — Evans \& Smith 2005: 12 (checklist); 2007: 12 (checklist); 2009: 12 (checklist).

\section{Type material examined}

\section{Holotype}

PERU - Ō; "Peru / Vitoc, 1400 to 1800m ix-22-40 / Coll of Bob Potts / L.W. Saylor Collection / California Academy of Sciences Type no 7917 / Holotype Astaena pygidia L.W. Saylor"; CAS.

\section{Holotype redescription}

MeAsurements. Length: $8 \mathrm{~mm}$. Width: $4 \mathrm{~mm}$.

HEAD. Reddish-brown. Labroclypeus, shape of anterior margin weakly sinuated medially, posteriorly with sparse punctation. Ocular canthus with terminal setae, ratio to eye: $1 / 3$. Antennae with eight antennomeres; antennal club with three antennomeres; ratio antennal club/remaining antennomeres: $1 / 1$; ratio third vs fourth antennomere: $1 / 3$; fourth antennomere, lateral projection absent; ratio fifth vs fourth antennomere: $1 / 5$.

Pronotum AND elytra. Surface of pronotum and elytra without setae. Pronotum unicolored, brownishorange, widest at middle, posterior marginal line absent, lateral margin strongly convex and smooth (not serrate), postero-lateral angle dorso-ventrally not flattened, punctation on disc sparse, setae of lateral margin sparse, median longitudinal excavation absent. Scutellum, punctures absent medially. Elytra unicolored, brownish-orange, surface opaque, microsculpture absent, punctation on intervals present and sparse, diameter of strial and interval punctation equal.

ABDomen. Lateral carina absent. Second visible ventrite without row of setae in medial region. Apical visible ventrite without suture to apical tergite.

LEGS. Metacoxa without longer lateral bristles, a laterally extended longitudinal shelf present. Metatibia, widest at apex, ventral margin serrated, distal spines groups disposed at two thirds of metatibial length. First metatarsomere, ratio to dorsal metatibial spur: 1/3. Dorsal surface of tarsi glabrous, without punctures. Metatarsi, length of first protarsomere subequal to second and third combined, ventral margin setose. Protibia with three teeth. Protarsi, second protarsomere narrow, claws asymmetrical, inner protarsal claw bifid, apex of basal tooth of inner protarsal claw truncate.

Aedeagus. Fig. 4A-B.

\section{Astaena rugithorax Saylor, 1946}

Figs 4F-I, 7B

Astaena rugithorax Saylor, 1946: 222.

Astaena rugithorax - Frey 1973: 364 (identification key). — Evans 2003: 28 (checklist). — Evans \& Smith 2005: 13 (checklist); 2007: 13 (checklist); 2009: 13 (checklist). 


\section{Type material examined}

\section{Holotype}

COLOMBIA - + ; "Colombia, S. A. / L.W. Saylor Collection / California Academy of Sciences Type nº 7918 / Holotype Astaena rugithorax L.W. Saylor”; CAS.

\section{Holotype redescription}

MeAsurements. Length: $14 \mathrm{~mm}$. Width: $7 \mathrm{~mm}$.

HEAD. Blackish-brown, surface with setae. Labroclypeus, shape of anterior margin straight, posteriorly with dense punctation. Ocular canthus without terminal setae, ratio to eye: $1 / 3$. Ratio fifth vs fourth antennomere: $1 / 5$.

Pronotum AND ElYTRA. Surface of pronotum and elytra without setae. Pronotum unicolored, blackishbrown, widest at middle, anterior marginal line present, posterior marginal line absent, lateral margin strong convex and serrated, antero-lateral angle dorso-ventrally flattened, postero-lateral angle dorsoventrally not flattened, punctation on disc dense, setae of lateral margin sparse, median longitudinal excavation absent. Scutellum, punctures absent medially. Elytra unicolored, blackish-brown, surface opaque, microsculpture absent, punctation on intervals present and sparse, diameter of strial and interval punctation equal.

AвDOMEN. Lateral carina absent. Second visible ventrite without row of setae in medial region. Apical visible ventrite without suture to apical tergite.

LEGS. Metacoxa without longer lateral bristles, a laterally extended longitudinal shelf absent. Metatibia, widest at apex, distal spines groups disposed at half size of metatibial length. First metatarsomere, ratio to dorsal metatibial spur: 1/2. Dorsal surface of tarsi glabrous, without punctures. Metatarsi, length of first protarsomere subequal to second and third combined, ventral margin serrated and setose. Protibia with three teeth. Protarsi, length of first protarsomere subequal to second and third combined, second protarsomere narrow, claws symmetrical, inner protarsal claw bifid, apex of basal tooth of inner protarsal claw acute.

\section{Male}

Unknown.

Astaena salta Saylor, 1946

Figs 4J-M, 7B

Astaena salta Saylor, 1946: 231.

Astaena salta - Frey 1973: 336 (identification key). — Evans 2003: 28 (checklist). — Evans \& Smith 2005: 13 (checklist); 2007: 13 (checklist); 2009: 13 (checklist).

\section{Type material examined}

Holotype

ARGENTINA - + ; "Salta, Arg. viii / L.W. Saylor Collection / California Academy of Sciences Type no 7919 / Holotype Astaena salta L.W. Saylor"; CAS.

\section{Holotype redescription}

Measurements. Length: $5 \mathrm{~mm}$. Width: $3 \mathrm{~mm}$. 


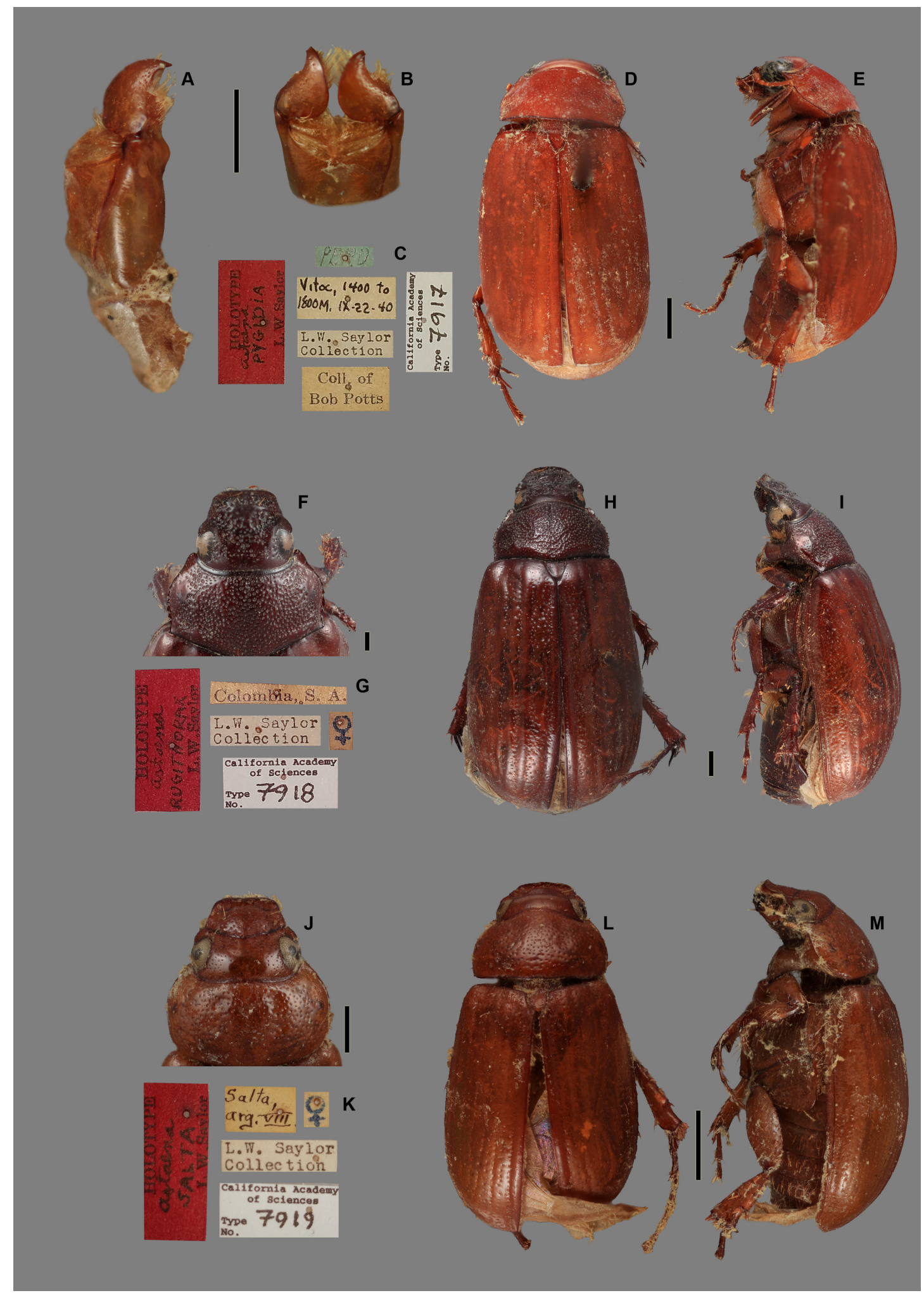

Fig. 4. A-E. Astaena pygidia Saylor, 1946, holotype, đ̊ (Type No. 7917; CAS). - F-I. A. rugithorax Saylor, 1946, holotype, + (Type No. 7918; CAS). - J-M. A. salta Saylor, 1946, holotype, + (Type No. 7919; CAS). A. Aedeagus, lateral view. B. Parameres, dorsal view. C, G, K. Labels. D, H, L. Habitus, dorsal view. E, I, M. Habitus, lateral view. F, J. Head and pronotum, dorsal view. Scale bars: A-B, F, J = $0.5 \mathrm{~mm}$; D-E, H-I, L-M = $1 \mathrm{~mm}$. 
HEAD. Reddish-brown, surface with setae. Labroclypeus, shape of anterior margin convex, posteriorly with dense punctation. Ocular canthus without terminal setae, ratio to eye: $1 / 3$. Antennae with eight antennomeres; antennal club with three antennomeres; ratio antennal club/remaining antennomeres: $1 / 1.5$; ratio third vs fourth antennomere: $1 / 2$; fourth antennomere, lateral projection absent; ratio fifth vs fourth antennomere: $1 / 5$.

Pronotum AND elYTRa. Surface of pronotum and elytra with setae. Pronotum unicolored, reddishbrown, widest at middle, anterior marginal line present, posterior marginal line absent, lateral margin weakly convex and not serrated, antero-lateral angle dorso-ventrally not flattened, postero-lateral angle dorso-ventrally not flattened, punctation on disc dense, setae of lateral margin sparse, median longitudinal excavation absent. Scutellum, punctures absent medially. Elytra unicolored, reddish-brown, surface opaque, microsculpture absent, punctation on intervals present and sparse, diameter of strial and interval punctation equal.

AвDOMEN. Lateral carina absent. Second visible ventrite without row of setae in medial region. Apical visible ventrite without suture to apical tergite.

LEGS. Metacoxa without longer lateral bristles, a laterally extended longitudinal shelf present. Metatibia, widest at apex, distal spines groups disposed at two thirds of metatibial length. First metatarsomere, ratio to dorsal metatibial spur: 1/3. Dorsal surface of tarsi glabrous, without punctures. Metatarsi, ventral margin serrated and glabrous. Protibia with two teeth. Protarsi, length of first protarsomere subequal to second and third combined, second protarsomere narrow.

\section{Male}

Unknown.

Astaena yungasa Saylor, 1946

Figs 5A-E, 7B

Astaena yungasa Saylor, 1946: 217.

Astaena yungasa - Frey 1973: 333 (identification key). — Evans 2003: 31 (checklist). — Evans \& Smith 2005: 15 (checklist); 2007: 15 (checklist); 2009: 15 (checklist).

\section{Type material examined}

\section{Holotype}

BOLIVIA - गे; "Yungas, Bolivia / L.W. Saylor Collection / California Academy of Sciences Type $\mathrm{n}^{\circ} 7920$ / Holotype Astaena yungasa L.W. Saylor"; CAS.

\section{Paratype}

BOLIVIA • 1 đ̃; "Yungas, Bolivia / L.W. Saylor Collection / Paratype Astaena yungasa L.W. Saylor / CASENT 8438307”; CAS.

\section{Holotype redescription}

MeAsurements. Length: $14 \mathrm{~mm}$. Width: $6.75 \mathrm{~mm}$.

HEAD. Blackish-brown, surface with upright setae. Labroclypeus, shape of anterior margin weakly sinuated medially, posteriorly with dense punctation. Ocular canthus with terminal setae, ratio to eye: 1/3. Eyes, ratio diameter/interocular width: 0.68. Antennae with eight antennomeres. Antennal club 
with three antennomeres. Ratio antennal club/remaining antennomeres: 1/1. Ratio third vs fourth antennomere: $1 / 4$. Fourth antennomere, lateral projection absent. Ratio fifth vs fourth antennomere: 1/5.

Pronotum and elytra. Surface of pronotum and elytra with setae. Pronotum unicolored, blackishbrown, widest at middle, anterior marginal line present, posterior marginal line absent, lateral margin strongly convex and smooth (not serrate), antero-lateral angle dorso-ventrally not flattened, posterolateral angle dorso-ventrally not flattened, punctation on disc sparse, setae of lateral margin dense, median longitudinal excavation absent. Scutellum, punctures absent medially. Elytra unicolored, reddish-brown, surface opaque, microsculpture absent, punctation on intervals present and sparse, diameter of strial and interval punctation equal.

AвDomen. Lateral carina present. Second visible ventrite without row of setae in medial region. Apical visible ventrite without suture to apical tergite.

LEGS. Ratio of length of metepisternum/metacoxa: 1/0.86. Metacoxa without longer lateral bristles, a laterally extended longitudinal shelf absent. Metatibia, widest at apex, ratio of width/length: 1/4.83, dorsal margin not carinated, ventral margin serrated, distal spines groups disposed at two thirds of metatibial length. First metatarsomere, ratio to dorsal metatibial spur $1 / 2$. Dorsal surface of tarsi glabrous, with punctures. Metatarsi, length of first protarsomere subequal to second and third combined, ventral margin serrated and setose. Protibia with three teeth. Protarsi, length of first protarsomere subequal to second and third combined, second protarsomere narrow, claws asymmetrical, inner protarsal claw bifid, apex of basal tooth of inner protarsal claw truncate.

Aedeagus. Fig. 5A-B.

Astaena zyrota Saylor, 1946

Figs 5F-J, 7B

Astaena zyrota Saylor, 1946: 232.

Astaena zyrota - Frey 1973: 352 (identification key). — Evans 2003: 31 (checklist). — Evans \& Smith 2005: 15 (checklist); 2007: 16 (checklist); 2009: 16 (checklist).

\section{Type material examined}

Holotype

GUIANA • \; "Tumatumari VI Br Guiana / L.W. Saylor Collection / California Academy of Sciences Type $\mathrm{n}^{\circ} 7921$ / Holotype Astaena zyrota L.W. Saylor”; CAS.

\section{Holotype redescription}

MEASUREMENTS. Length: $7.5 \mathrm{~mm}$. Width: $4.5 \mathrm{~mm}$.

HEAD. Reddish-brown, surface without setae. Labroclypeus, shape of anterior margin weakly sinuated medially, posteriorly with sparse punctation. Ocular canthus without terminal setae, ratio to eye: 1/4. Antennae with eight antennomeres; antennal club with three antennomeres; ratio antennal club/remaining antennomeres: $1 / 1.5$; ratio third vs fourth antennomere: $1 / 3$; fourth antennomere, lateral projection absent; ratio fifth vs fourth antennomere: $1 / 5$.

Pronotum And elytra. Pronotum unicolored, reddish-brown, widest at middle, anterior marginal line present, posterior marginal line absent, lateral margin weakly convex and not serrated, antero-lateral angle dorso-ventrally not flattened, postero-lateral angle dorso-ventrally not flattened, punctation on 


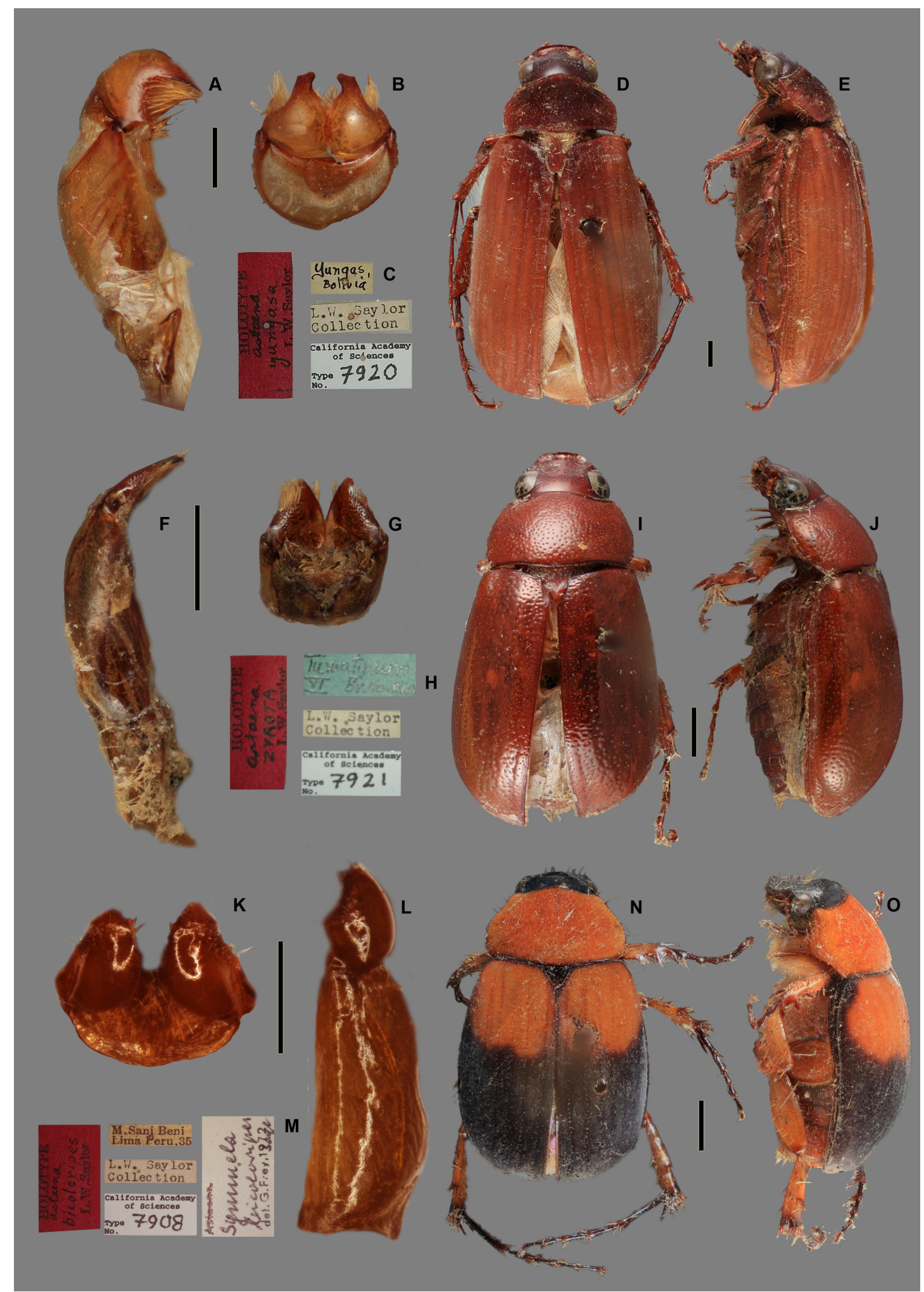

Fig. 5. A-E. Astaena yungasa Saylor, 1946, holotype, ð̋ (Type No. 7920; CAS). - F-J. A. zyrota Saylor, 1946, holotype, §ิ (Type No. 7921; CAS). - K-L. Sayloria bicoloripes (Saylor, 1946), paratype, đ (CAS). - M-O. S. bicoloripes, holotype, o (Type No. 7908; CAS). A, F, L. Aedeagus, lateral view. B, G, K. Parameres, dorsal view. C, H, M. Labels. D, I, N. Habitus, dorsal view. E, J, O. Habitus, lateral view. Scale bars: A-B, F-G, K-L $=0.5 \mathrm{~mm}$; D-E, I-J, N-O $=1 \mathrm{~mm}$. 
disc dense, setae of lateral margin sparse, median longitudinal excavation absent. Scutellum, punctures absent medially. Elytra unicolored, reddish-brown, surface opaque, microsculpture absent, punctation on intervals present, punctation on intervals dense, diameter of strial and interval punctation equal.

Abdomen. Lateral carina present. Second visible ventrite with row of setae in medial region. Apical visible ventrite without suture to apical tergite.

LEGS. Metacoxa without longer lateral bristles, a laterally extended longitudinal shelf absent. Metatibia, widest at apex, ventral margin not serrated, distal spines groups disposed at two thirds of metatibial length. First metatarsomere, ratio to dorsal metatibial spur: 1/2. Dorsal surface of tarsi glabrous, without punctures. Metatarsi, length of first protarsomere smaller than second and third combined, ventral margin glabrous. Protibia with three teeth. Protarsi, length of first protarsomere subequal to second and third combined, second protarsomere narrow, claws asymmetrical, inner protarsal claw bifid, apex of basal tooth of inner protarsal claw truncate.

Aedeagus. Fig. 5F-G.

Sayloria Frey, 1973

Sayloria Frey, 1973 (nec Chalumeau, 1981): 324 (as subgenus of Symmela).

Sayloria (as subgenus of Symmela Frey, 1973) - Evans 2003: 47 (checklist). — Evans \& Smith 2005: 29 (checklist); 2007: 29 (checklist); 2009: 30 (checklist).

\section{Type species}

Astaena bicoloripes Saylor, 1946 (by monotypy).

\section{Diagnosis}

Brown, reddish-brown, blackish coloration, often bicolored. Antennae with eight antennomeres; antennal club of males with three antennomeres. Abdomen without a robust lateral carina. Mentum deeply sinuated medially at anterior margin.

Sayloria bicoloripes (Saylor, 1946) comb. nov.

Figs $5 \mathrm{~K}-\mathrm{O}, 7 \mathrm{C}$

Astaena bicoloripes Saylor, 1946: 226.

Astaena postnodata Frey, 1973: 339 syn. nov.

Symmela (Sayloria) bicoloripes - Frey 1973: 324 (new subgenus, identification key).

Symmela bicoloripes - Evans 2003: 47 (checklist). — Evans \& Smith 2005: 29 (checklist); 2007: 30 (checklist); 2009: 30 (checklist).

Astaena postnodata - Evans 2003: 27 (checklist). — Evans \& Smith 2005: 12 (checklist); 2007: 12 (checklist); 2009: 12 (checklist).

\section{Type material examined}

Holotype (Astaena bicoloripes)

PERU • O; "M. Sani Beni Lima Peru. 35 / L.W. Saylor Collection / California Academy of Sciences Type ${ }^{\circ} 7908$ / Holotype Astaena bicoloripes L.W. Saylor / Symmela bicoloripes Saylor det. G. Frey"; CAS. 
PACHECO T.L. et al., Type specimens of Astaena described by Saylor

Paratype (Astaena bicoloripes)

PERU • 1 §̧; "M. Sani Beni Lima Peru. 35 / L.W. Saylor Collection / Paratype Astaena bicoloripes L.W. Saylor / Astaena bicoloripes Saylor / CASENT 8438129”; CAS.

Holotype (Astaena postnodata)

PERU • đ̃; “Mt. Alegre, Rio Pachitea O. Peru G. Tessmann / Type Astaena postnodata G. Frey 1973”; ZMHB.

Paratypes (Astaena postnodata)

PERU • 4 우; “Mt. Alegre, Rio Pachitea O. Peru G. Tessmann / Paratype Astaena postnodata G. Frey 1973”; ZMHB.

\section{Additional material examined}

PERU • 1 ơ; "Dept. Cusco, PERU Santa Isabel Cosnipata Valley Dec 51951 Felix Woytkowski / H. \&

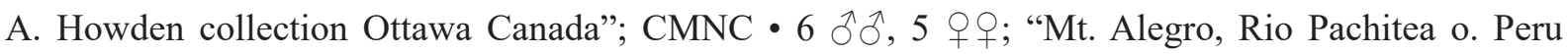
G. Tessmann"; ZFMK, ZMHB, NHMB.

\section{Holotype redescription}

MeASurements. Length: $6.5 \mathrm{~mm}$. Width: $4 \mathrm{~mm}$.

HEAD. Black, surface with upright setae. Labroclypeus convex, shape of anterior margin weakly sinuated medially, posteriorly with dense punctation. Ocular canthus with terminal setae, ratio to eye: $1 / 3$. Eyes, ratio diameter/interocular width: 0.44 . Antennae with nine antennomeres; antennal club with three antennomeres; ratio antennal club/remaining antennomeres: $1 / 1$; ratio third vs fourth antennomere: $1 / 2$; fourth antennomere, lateral projection absent; ratio fifth vs fourth antennomere: 1.2/1.

Pronotum AND ELYTRA. Surface of pronotum and elytra without setae. Pronotum unicolored, brownishorange, widest at base, anterior marginal line present, posterior marginal line absent, lateral margin strongly convex and smooth (not serrate), antero-lateral angle dorso-ventrally not flattened, posterolateral angle dorso-ventrally not flattened, punctation on disc dense, setae of lateral margin sparse, median longitudinal excavation present. Scutellum, punctures medially present. Elytra bicolored, surface opaque, microsculpture absent, punctation on intervals present and sparse, diameter of strial and interval punctation equal.

ABDOMEN. Lateral carina present. Second visible ventrite without row of setae in medial region. Apical visible ventrite without suture to apical tergite.

LEGS. Ratio of length of metepisternum/metacoxa: 1/0.90. Metacoxa without longer lateral bristles, a laterally extended longitudinal shelf present. Metatibia, widest at apex, ratio of width/length: 1/3, dorsal margin not carinated. ventral margin serrated, distal spines groups disposed at two thirds of metatibial length. First metatarsomere, ratio to dorsal metatibial spur: 1/3. Dorsal surface of tarsi glabrous, without punctures. Metatarsi, length of first protarsomere subequal to second and third combined, ventral margin serrated and setose. Protibia with three teeth. Protarsi, length of first protarsomere subequal to second and third combined, second protarsomere narrow, claws asymmetrical, inner protarsal claw bifid, apex of basal tooth of inner protarsal claw truncate.

Aedeagus. Fig. 5K-L. 


\section{Remarks}

Also, in this case, the holotype was a female specimen; Saylor mentioned in the original description that the holotype was a male.

Sayloria abcora (Saylor, 1946) comb. nov.

Figs 6A-I, 7C

Astaena abcora Saylor, 1946: 224.

Astaena apolinar-maria Saylor, 1946 syn. nov.

Astaena abcora - Frey 1973: 348 (identification key). — Evans 2003: 19 (checklist). — Evans \& Smith 2005: 29 (checklist); 2007: 30 (checklist); 2009: 30 (checklist).

Astaena apolinar-maria - Frey 1973: 352 (identification key).

Astaena apolinarmaria Evans 2003: 19 (spelling corrected, checklist). — Evans \& Smith 2005: 29

(checklist); 2007: 30 (checklist); 2009: 30 (checklist).

\section{Type material examined}

Holotype (Astaena abcora)

COLOMBIA - O'; "Buenaventura alt. 3500-4000 ft. Colombia, ii-3 / L.W. Saylor Collection / California Academy of Sciences Type n 7905 / Holotype Astaena abcora L.W. Saylor”; CAS.

Paratype (Astaena abcora)

COLOMBIA • 1 q ; "Buenaventura alt. 3500-4000 ft. Colombia, ii-3 / L.W. Saylor Collection / Collection of the California Academy of Sciences, San Francisco, California / Allotype Astaena abcora L.W. Saylor / CASENT 8438114"; CAS.

Holotype (Astaena apolinarmaria)

COLOMBIA • + ; "Pensilvania Colomb / L.W. Saylor Collection / California Academy of Sciences Type nº 7906 / Apolinar-Maria / Holotype Astaena apolinar-maria L.W. Saylor”; CAS.

\section{Additional material examined}

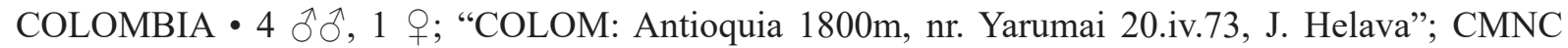
- 19 ふ઼

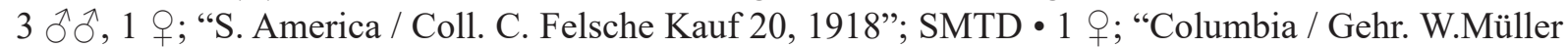
Vermächt., 1909"; SMTD • 1 ○; "Cauca / Coll. C. Felsche Kauf 20, 1918”; SMTD • 1 ๆ; "Columbia Cañon de Gallo / Astaena apollinarmaria Sayl. Det. G. Frey, 1972 / cum typo comparatum”; NHMB.

\section{Holotype redescription}

MEASUREMENTs. Length: $7 \mathrm{~mm}$. Width: $3.75 \mathrm{~mm}$.

HEAD. Black, surface with simple setae. Labroclypeus, shape of anterior margin weakly sinuated medially, posteriorly with sparse punctation. Ocular canthus with terminal setae, ratio to eye: $1 / 3$. Eyes, ratio diameter/interocular width: 0.40 . Antennae with eight antennomeres; antennal club with three antennomeres; ratio antennal club/remaining antennomeres: $1 / 1.5$; ratio third vs fourth antennomere: $1 / 2$; fourth antennomere, lateral projection absent; ratio fifth vs fourth antennomere: $1 / 5$.

Pronotum AND elYTRA. Surface of pronotum and elytra without setae. Pronotum bicolored, widest at base, anterior marginal line present, posterior marginal line absent, lateral margin weakly convex and serrated, antero-lateral angle dorso-ventrally flattened, postero-lateral angle dorso-ventrally not 


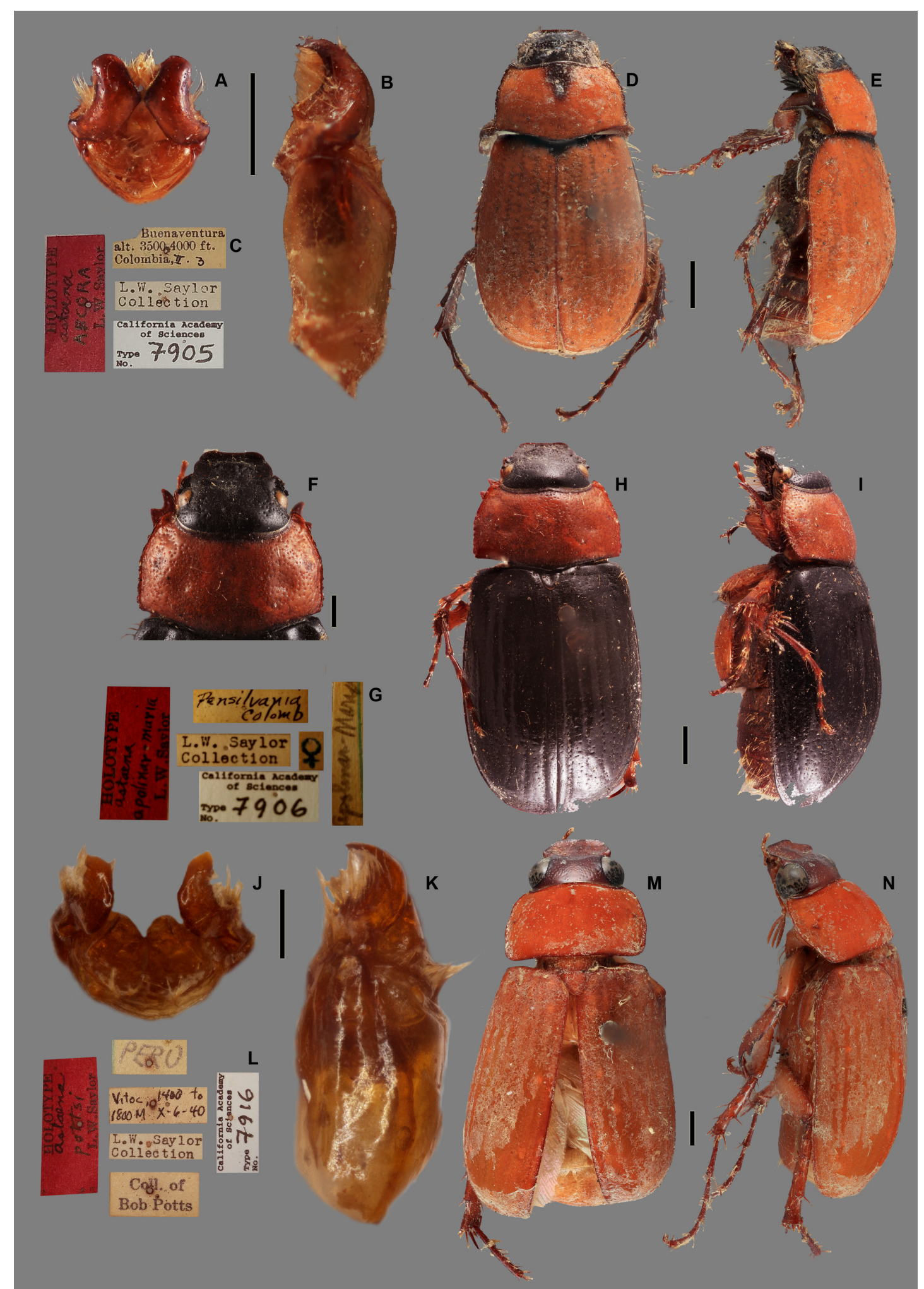

Fig. 6. A-E. Sayloria abcora (Saylor, 1946), holotype, ô (Type No. 7905; CAS). - F-I. Astaena apolinarmaria Saylor, 1946, holotype, o (Type No. 7906; CAS). - J-K. Sayloria pottsi (Saylor, 1946),

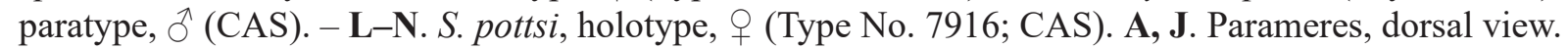
B, K. Aedeagus, lateral view. C, G, L. Labels. D, H, M. Habitus, dorsal view. E, I, N. Habitus, lateral view. F. Head and pronotum, dorsal view. Scale bars: A-B, F, J-K =0.5 mm; D-E, H-I, M-N = $1 \mathrm{~mm}$. 
flattened, punctation on disc sparse, setae of lateral margin dense, median longitudinal excavation absent. Scutellum, punctures absent medially. Elytra unicolored, brownish-orange, surface opaque, microsculpture absent, punctation on intervals present, sparse, diameter of strial and interval punctation equal, posterior edge straight.

AbDomen. Lateral carina absent. Second visible ventrite without row of setae in medial region. Apical visible ventrite without suture to apical tergite.

LeGs. Ratio of length of metepisternum/metacoxa: 1/0.77. Metacoxa without longer lateral bristles, a laterally extended longitudinal shelf present. Metatibia, widest at apex, ratio of width/length: 1/3.34, dorsal margin carinated, ventral margin not serrated, distal spines groups disposed at two thirds of metatibial length. First metatarsomere, ratio to dorsal metatibial spur: $1 / 2$. Dorsal surface of tarsi glabrous, without punctures. Metatarsi, length of first protarsomere subequal to second and third combined, ventral margin serrated and glabrous. Protibia with three teeth. Protarsi, length of first protarsomere subequal to second and third combined, second protarsomere narrow, claws symmetrical, inner protarsal claw bifid, apex of basal tooth of inner protarsal claw acute.

Aedeagus. Fig. 6A-B.

\section{Remarks}

There is no difference between female type specimens of $S$. abcora and $S$. apolinarmaria except coloration, which is very variable. Therefore, we consider them synonymous.

Sayloria pottsi (Saylor, 1946) comb. nov.

Figs $6 \mathrm{~J}-\mathrm{N}, 7 \mathrm{C}$

Astaena pottsi Saylor, 1946: 217.

Astaena pottsi - Frey 1973: 339 (identification key). — Evans 2003: 27 (checklist). — Evans \& Smith 2005: 12 (checklist); 2007: 12 (checklist); 2009: 12 (checklist).

\section{Type material examined}

Holotype

PERU • + ; "Peru / Vitoc, 1400 to 1800m x-6-40 / Coll. of Bob Potts / L.W. Saylor Collection / California Academy of Sciences Type n 7916 / Holotype Astaena pottsi L.W. Saylor"; CAS.

Paratypes

PERU • 1 P; "Peru / Vitoc, 1400 to 1800m ix-22-40 / Coll. of Bob Potts / L.W. Saylor Collection / Collection of the California Academy of Sciences, San Francisco, California / Allotype Astaena pottsi L.W. Saylor / CASENT 8438229"; CAS • 1 đ̊; "Vitoc, 1400 to 1800m ix-13-40 / Coll. of Bob Potts / L.W. Saylor Collection / Paratype Astaena pottsi L.W. Saylor / Locality label should read Vitor, PERU / CASENT 8438221"; CAS • 1 q; "Peru / Vitoc, 1400 to 1800m ix-3-40 / Coll. of Bob Potts / Paratype Astaena pottsi L.W. Saylor / Locality label should read Vitor, PERU / CASENT 8438222”; CAS.

\section{Holotype redescription}

MEASUREMENTs. Length: $11 \mathrm{~mm}$. Width: $5 \mathrm{~mm}$.

HEAD. Reddish-brown, surface with setae. Labroclypeus, shape of anterior margin straight, posteriorly with sparse punctation. Ocular canthus with terminal setae, ratio to eye: 1/4. Eyes, ratio diameter/interocular width: 0.7. Antennae with eight antennomeres; antennal club with three antennomeres; ratio antennal 
PACHECO T.L. et al., Type specimens of Astaena described by Saylor

club/remaining antennomeres: $1 / 1.5$; ratio third vs fourth antennomere: $1 / 2$; fourth antennomere, lateral projection absent; ratio fifth vs fourth antennomere: $1 / 5$.

Pronotum and elytra. Surface of pronotum and elytra without setae. Pronotum unicolored, brownishorange, widest at middle, lateral margin weakly convex and not serrated, antero-lateral angle dorsoventrally not flattened, postero-lateral angle dorso-ventrally not flattened, punctation on disc sparse, setae of lateral margin sparse, median longitudinal excavation present. Scutellum, punctures absent medially. Elytra unicolored, brownish-orange, surface opaque, microsculpture absent, punctation on intervals present and dense, diameter of strial and interval punctation equal.

ABDOMEN. Lateral carina absent. Second visible ventrite without row of setae in medial region. Apical visible ventrite without suture to apical tergite.

LEGS. Ratio of length of metepisternum/metacoxa: 1/1.12. Metacoxa without longer lateral bristles, a laterally extended longitudinal shelf present. Metatibia, widest at apex, ratio of width/length: 1/3.88, dorsal margin not carinated, ventral margin not serrated, distal spines groups disposed at two thirds of metatibial length. First metatarsomere, ratio to dorsal metatibial spur: 1/3. Dorsal surface of tarsi glabrous, without punctures. Metatarsi, length of first protarsomere subequal to second and third combined, ventral margin setose. Protibia with three teeth. Protarsi, length of first protarsomere subequal to second and third combined, second protarsomere narrow, claws symmetrical, inner protarsal claw bifid, apex of basal tooth of inner protarsal claw acute.

Aedeagus. Fig. 6J-K.

\section{Discussion}

The current revision treated the types described by L.W. Saylor, of which six of 18 taxa are known only from females. This represents nearly $35 \%$ of the species, which makes a comprehensive taxonomic treatment difficult since generally all species of Sericini are distinguished with confidence only through the examination of male genitalia. Although external morphology, including shape and surface structure of head, pronotum, and elytra, is relatively stable in South American Sericini compared to Old World Sericini lineages, the taxonomy of the species is complicated by the fact that sexual dimorphism is extreme in many species. Dimorphism is not only apparent in the shape of tarsi and pygidium, but also in body color and surface sheen; thus males and females of the same species are often not easily associated initially (e.g., Sayloria abcora).

We were able to identify Sayloria Frey, 1973 as a separate genus based on a comprehensive and comparative preliminary review of morphological characters within South American Sericini (Pacheco et al. in preparation). Exclusive hypothesized synapomorphies of Sayloria include mouthpart characters (e.g., the deeply excised anterior margin of the mentum) and the absence of a robust lateral carina on abdominal ventrites. Given the high degree of homoplasy in many morphological traits of Sericini that make a generic systematic very difficult (e.g., Ahrens 2006b, 2006c; Ahrens \& Vogler 2008; Liu et al. 2015; Frings et al. 2020), results from comparative morphology will need to be supported by evidence from future molecular phylogenies.

\section{Acknowledgments}

We thank Christopher Grinter for the loan of the specimens from Californian Academy of Sciences (CAS), and Eugenio Nearns for help with pictures, procedures and a warm welcome at the Smithsonian Institution, Washington D.C. (USNM) to both TLP and MLM. Also, we are very grateful to Terry Erwin, Floyd Shockley and Charyn Micheli for receiving TLP at USNM. Furthermore, we are thankful for the helpful comments of two anonymous referees on the earlier version of the manuscript. This 


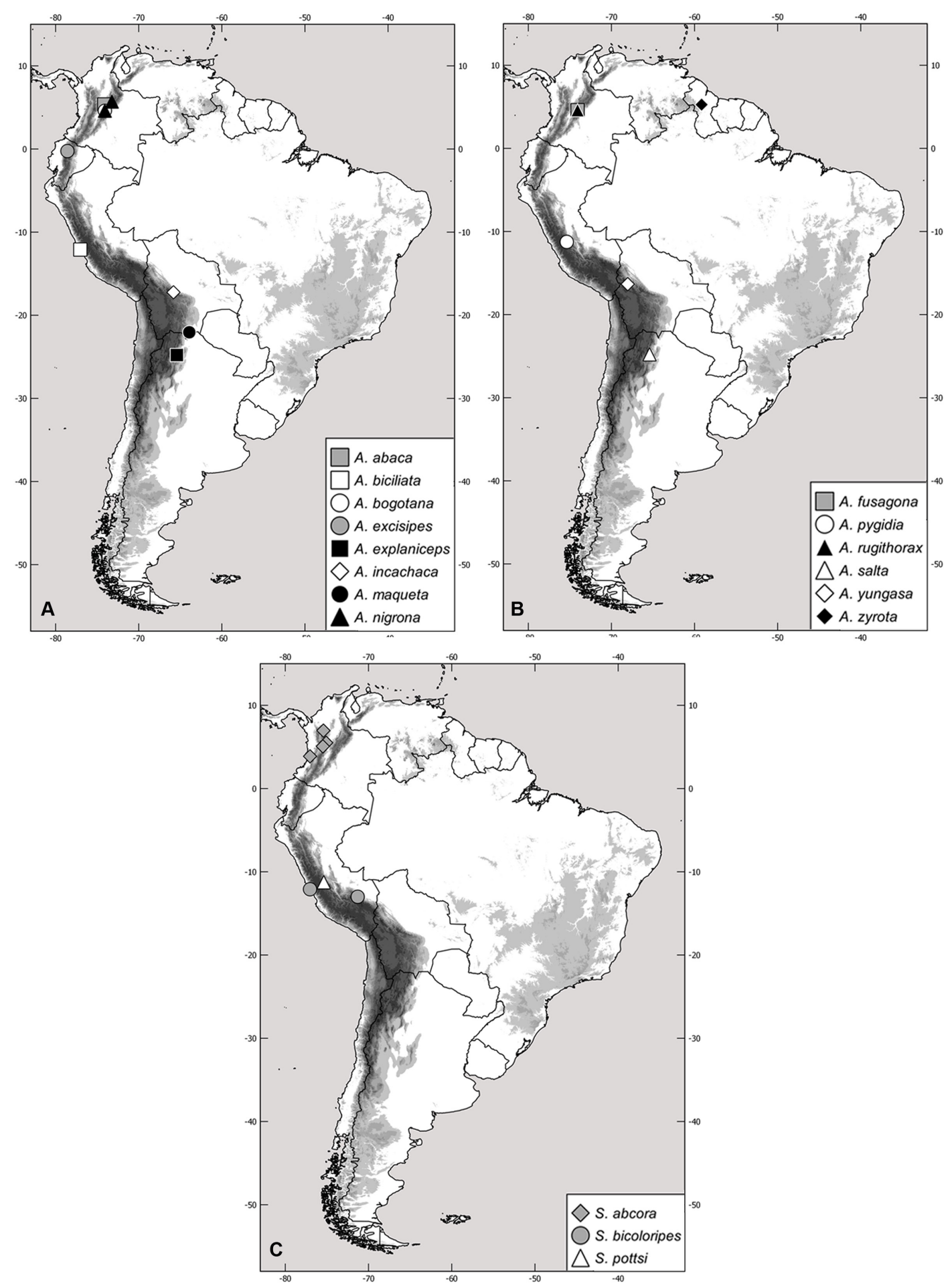

Fig. 7. Distribution of type localities of the South American Sericini species described by Saylor. A. Astaena abaca Saylor, 1946, A. biciliata Saylor, 1946, A. bogotana Saylor, 1946, A. excisipes Saylor, 1947, A. explaniceps Saylor, 1947, A. incachaca Saylor, 1946, A. maqueta Saylor, 1947, and A. nigrona Saylor, 1947. B. A. fusagona Saylor, 1946, A. pygidia Saylor, 1946, A. rugithorax Saylor, 1946, A. salta Saylor, 1946, A. yungasa Saylor, 1946, and A. zyrota Saylor, 1946. C. Sayloria abcora (Saylor, 1946) comb. nov., S. bicoloripes (Saylor, 1946) comb. nov., and S. pottsi (Saylor, 1946) comb. nov.. 
PACHECO T.L. et al., Type specimens of Astaena described by Saylor

work was supported by US Department of State, Smithsonian Institute, Fulbright Commission in Brazil, Coordenação de Aperfeiçoamento de Pessoal de Nível Superior (CAPES/PRINT) under grant 88887.368189/2019-00, and Conselho Nacional de Desenvolvimento Científico e Tecnológico (CNPq) under grants 142383/2017-1 (TLP), 304318/2018-3 (MLM), and 306745/2016-0 (FZV).

\section{References}

Ahrens D. 2004a. Monographie der Sericini des Himalaya (Coleoptera, Scarabaeidae). dissertation.de - Verlag im Internet GmbH, Berlin.

Ahrens D. 2004b. Revisional notes on Sericinae: The taxonomic status of the "Neotropical" genus Rhynchosymmela Frey, 1974 (Coleoptera, Scarabaeidae). Beiträge zur Entomologie 54: 31-35. https://doi.org/10.21248/contrib.entomol.54.1.31-35

Ahrens D. 2006a. The phylogeny of Sericini and their position within the Scarabaeidae based on morphological characters (Coleoptera: Scarabaeidae). Systematic Entomology 31: 113-144. https://doi.org/10.1111/j.1365-3113.2005.00307.x

Ahrens D. 2006b. The phylogeny of the genus Lasioserica inferred from adult morphology - implications on the evolution of montane fauna of the South Asian orogenic belt (Coleoptera: Scarabaeidae: Sericini). Journal of Zoological Systematics and Evolutionary Research 44: 34-53.

https://doi.org/10.1111/j.1439-0469.2005.00340.x

Ahrens D. 2006c. Cladistic analysis of Maladera (Omaladera): implications on taxonomy, evolution and biogeography of the Himalayan species (Coleoptera: Scarabaeidae: Sericini). Organisms, Diversity \& Evolution 6: 1-16. https://doi.org/10.1016/j.ode.2005.01.002

Ahrens D. \& Fabrizi S. 2016. A monograph of the Sericini of India (Coleoptera: Scarabaeidae). Bonn Zoological Bulletin 65: 1-355.

Ahrens D. \& Vogler A.P. 2008. Towards the phylogeny of chafers (Sericini): analysis of alignmentvariable sequences and the evolution of segment numbers in the antennal club. Molecular Phylogenetics and Evolution 47: 783-798. https://doi.org/10.1016/j.ympev.2008.02.010

Blanchard C.E. 1850. Ordre des Coléoptéres. In: Milne-Edwards H., Blanchard E. \& Lucas H. (eds) Muséum d'histoire naturelle de Paris. Catalogue de la Collection entomologique. Classe des Insectes: 1-128. Gide and Baudry, Paris.

Burmeister H. 1855. Handbuch der Entomologie. Vierter Band. Zweite Abtheilung. Coleoptera Lamellicornia Phyllophaga Chaenochela. T.C.F. Enslin, Berlin.

Chalumeau F. 1981. Nouveaux genre et sous-genres d'Eupariini (Aphodiinae) d'Amérique tropicale. Nouvelle Revue d'Entomologie 11: 137-142.

Eberle J., Fabrizi S., Lago P. \& Ahrens D. 2017a. A historical biogeography of megadiverse Sericini another story "out of Africa”? Cladistics 33: 183-197. https://doi.org/10.1111/cla.12162

Eberle J., Beckett M., Özgül-Siemund A., Frings J., Fabrizi S. \& Ahrens D. 2017b. Afromontane forests hide 19 new species of ancient chafer lineage (Coleoptera: Scarabaeidae): Pleophylla Erichson, 1847 phylogeny and taxonomic revision. Zoological Journal of Linnean Society 180: 321-353.

Erichson W.F. 1835. Neue Südamerikanische Käfergattungen aus der Familie der Blätterbürner. Archiv für Naturgeschichte 256-270.

Erichson W.F. 1847. Conspectus insectorum coleopterorum quae in Republica Peruana observata sunt. Archiv für Naturgeschichte 67-185. 
Evans A.V. 2003. A checklist of the New World chafers (Coleoptera: Scarabaeidae: Melolonthinae). Zootaxa 211: 1-458. https://doi.org/10.11646/zootaxa.211.1.1

Evans A.V. \& Smith A.B.T. 2005. An Electronic Checklist of the New World Chafers (Coleoptera: Scarabaeidae: Melolonthinae). Version 1. Electronically published, Ottawa, Canada.

Evans A.V. \& Smith A.B.T. 2007. An Electronic Checklist of the New World Chafers (Coleoptera: Scarabaeidae: Melolonthinae). Version 2. Electronically published, Ottawa, Canada.

Evans A.V. \& Smith A.B.T. 2009. An Electronic Checklist of the New World Chafers (Coleoptera: Scarabaeidae: Melolonthinae). Version 3. Electronically published, Ottawa.

Fabrizi S. \& Ahrens D. 2014. A monograph of the Sericini of Sri Lanka (Coleoptera: Scarabaeidae). Bonn Zoological Bulletin Supplements 61: 1-124.

Fabrizi S., Eberle J. \& Ahrens D. 2019a. Unexpected diversity of Hyboserica chafers in South African forest remains: phylogenetic analysis, a new genus and 32 new species (Coleoptera: Scarabaeidae: Melolonthinae). Zoological Journal of Linnean Society 186: 950-982.

https://doi.org/10.1093/zoolinnean/zly095

Fabrizi S., Dalstein V. \& Ahrens D. 2019b. A monograph on the genus Tetraserica from the Indochinese region (Coleoptera, Scarabaeidae, Sericini). ZooKeys 837: 1-155.

https://doi.org/10.3897/zookeys.837.32057

Frey G. 1973. Synopsis der südamerikanischen Sericinen. Entomologische Arbeiten aus dem Museum Frey 1973: 315-366.

Frey G. 1974. Neue Astaena-Arten aus Argentinien, Brasilien und Bolivien (Col., Melolonthidae, Sericinae). Entomologische Arbeiten aus dem Museum Frey 25: 131-135.

Frey G. 1975. Neue Melolonthiden und Ruteliden aus den Beständen der Zoologischen Staatssammlung München. Entomologische Arbeiten aus dem Museum Frey 26: 256-262.

Frey G. 1976. Neue Sericinae und Macrodactylini aus Brasilien (Col., Melolonthidae). Entomologische Arbeiten aus dem Museum Frey 27: 375-388.

Frings J., Lago P. \& Ahrens D. 2020. Morphology of mouthparts poorly resolves the phylogeny of Sericini chafers (Coleoptera: Scarabaeidae). Zoologischer Anzeiger 284: 53-65.

https://doi.org/10.1016/j.jcz.2019.11.008

Katovich K. 2008. A generic-level phylogenetic review of the Macrodactylini (Coleoptera: Scarabaeidae: Melolonthinae). Insecta Mundi 23: 1-78.

Kirsch T. 1865. Beiträge zur Käferfauna von Bogota. Berliner entomologische Zeitschrift 9: 40-104.

Kirsch T. 1885. Neue südamerikanische Käfer. Berliner entomologische Zeitschrift 29: 207-224. https://doi.org/10.1002/mmnd.18850290206

Lacordaire J.T. 1855. Histoire naturelle des insectes. Genera des Coléoptères, ou exposé méthodique et critique de tous les genres proposés jusqu'ici dans cet ordre d'insectes. Tome Troisème. Contenant les familles des Pecticornes et Lamellicornes. Librarie Encyclopedique de Roret, Paris.

Liu W.G., Eberle J., Bai M., Yang X.K. \& Ahrens D. 2015. A phylogeny of Sericini with particular reference to Chinese species using mitochondrial and ribosomal DNA (Coleoptera: Scarabaeidae). Organisms, Diversity \& Evolution 15: 343-350. https://doi.org/10.1007/s13127-015-0204-z

Liu W.G., Fabrizi S., Bai M., Yang X.K. \& Ahrens D. 2019. A taxonomic revision of Chinese Neoserica (sensu lato): final part (Coleoptera: Scarabaeidae: Sericini). Bonn Zoological Bulletin Supplement 64: $1-71$. 
PACHECO T.L. et al., Type specimens of Astaena described by Saylor

Maddison W.P. \& Maddison D.R. 2018. Mesquite: a modular system for evolutionary analysis. Version 3.51. Available from http://www.mesquiteproject.org [accessed 21 Apr. 2021].

Moser J. 1918. Beitrag zur Kenntnis der Melolonthiden. VII. Deutsche entomologische Zeitschrift 1918: 293-356.

Moser J. 1921a. Beitrag zur Kenntnis der Melolonthiden. Stettiner entomologische Zeitung 82: 48-73.

Moser J. 1921b. Neue Melolonthiden von Mittel- und Südamerika. Stettiner entomologische Zeitung 82: $133-182$.

Moser J. 1924. Beitrag zur Kenntnis der Melolonthiden. XIII. Stettiner entomologische Zeitung 84: $114-136$.

Moser J. 1926. Beitrag zur Kenntnis der Melolonthiden. XIV. Stettiner entomologische Zeitung 87: 198-208.

Ratcliffe B.C. 2016. Lawrence W. Saylor, Coleopterist Extraordinaire. The Coleopterists Bulletin 70: 279-287. https://doi.org/10.1649/0010-065X-70.2.279

Saylor L.W. 1946. New South American scarab beetles of the genus Astaena. Revista de Entomología 17: 215-232.

Saylor L.W. 1947a. Studies in the melolonthine scarab beetles genera of the American continents. No. V. Raysymmela, a new genus near Symmela Erichson. Revista de Entomología 18: 160-166.

Saylor L.W. 1947b. New South American scarab beetles of the genus Astaena. Revista de Entomología 18: 433-437.

Smith A.B.T. 2008. South American Melolonthinae (Coleoptera: Scarabaeidae) classification and nomenclature: some problems and solutions. Insecta Mundi 60: 1-28.

Smith A.B.T. \& Evans A.V. 2005. A supplement to the checklist of the New World chafers (Coleoptera: Scarabaeidae: Melolonthinae) with notes on their tribal classification. Zootaxa 1032: 29-60. https://doi.org/10.11646/zootaxa.1032.1.2

Smith A.B.T. \& Evans A.V. 2018. Taxonomic review of Athliini (Coleoptera: Scarabaeidae: Melolonthinae), a new tribe of scarab beetles endemic to South America. Zootaxa 4471: 279-308. https://doi.org/10.11646/zootaxa.4471.2.3

Manuscript received: 3 August 2020

Manuscript accepted: 3 March 2021

Published on: 19 May 2021

Topic editor: Nesrine Akkari

Section editor: Max Barclay

Desk editor: Radka Rosenbaumová

Printed versions of all papers are also deposited in the libraries of the institutes that are members of the EJT consortium: Muséum national d'histoire naturelle, Paris, France; Meise Botanic Garden, Belgium; Royal Museum for Central Africa, Tervuren, Belgium; Royal Belgian Institute of Natural Sciences, Brussels, Belgium; Natural History Museum of Denmark, Copenhagen, Denmark; Naturalis Biodiversity Center, Leiden, the Netherlands; Museo Nacional de Ciencias Naturales-CSIC, Madrid, Spain; Real Jardín Botánico de Madrid CSIC, Spain; Zoological Research Museum Alexander Koenig, Bonn, Germany; National Museum, Prague, Czech Republic. 